\title{
EFEKTIVITAS MODEL PEMBELAJARAN PROBLEM BASED LEARNING DAN PROBLEM SOLVING TERHADAP KEMAMPUAN BERPIKIR KREATIF MATEMATIKA
}

\author{
Wahyu Puji Astuti ${ }^{1}$, Wahyudi ${ }^{2}$, Endang Indarini ${ }^{3}$ \\ 1,2,3 Jurusan Pendidikan Guru Sekolah Dasar, Universitas Kristen Satya Wacana, Salatiga \\ e-mail292014136@student.uksw.edu ${ }^{1}, \underline{\text { bimb.yudhi@gmail.com }}{ }^{2}$, eindarini@gmail.com ${ }^{3}$
}

\begin{abstract}
ABSTRAK
Penelitian ini bertujuan untuk mengetahui efektifitas model Problem Based Learning dan Problem Solvingterhadap kemampuan kemampuan berpikir kreatif pada siswa kelas 4 SD. Penelitian ini termasuk penelitian eksperimen semu. Uji prasyarat menunjukan kedua kelompok homogen dan berdistribusi normal. Uji T menggunakan uji $t$ Independent Sample Test menunjukan thitung > t tabel yaitu 10,148 > 2,0281 dan signifikan $0,000<0,05$ yang berarti $\mathrm{H} 0$ ditolak dan Ha diterima. Hal ini menunjukan adanya perbedaan efektivitas yang signifikan. Selanjutnya dilakukan uji normalitas gain yang menunjukan bahwa model Problem Based Learninglebih efektif dibanding model Problem Solving terhadap kemampuan berpikir kreatif.
\end{abstract}

Kata kunci :Problem Based Learning,Problem Solving, berpikir kreatif

\begin{abstract}
This study aims to determine the effectiveness of Problem Based Learning and Problem Solving models on the creative thinking mathematics in grade 4 elementary school students. This study included quasi-experimental research. The prerequisite test shows both homogeneous groups and normally distributed. $\mathrm{T}$ test using $\mathrm{t}$ test Independent Sample Test shows $\mathrm{t}$ count $>\mathrm{t}$ tabel that is $10,148>2,0281$ and significant $0,000<0,05$ which means $\mathrm{H}_{0}$ rejected and $\mathrm{H}_{\mathrm{a}}$ accepted. This shows a significant difference in effectiveness. Furthermore, the gain normality test shows that the Problem Based Learning model is more effective than Problem Solving model of mathematical creative thinking.
\end{abstract}

Keyword :Problem Based Learning,Problem Solving, creative thinking

\section{PENDAHULUAN}

Lampiran I Permendiknas No. 22 Tahun 2006 menyatakan bahwa mata pelajaran matematika diberikan kepada semua peserta didik mulai dari sekolah dasar untuk membekali peserta didik dengan kemampuan berpikir logis, analitis, sistematis, kritis, dan kreatif, serta kemampuan bekerjasama. Kompetensi tersebut diperlukan agar peserta didik dapat memiliki kemampuan memperoleh, mengelola, dan memanfaatkan informasi untuk bertahan hidup pada keadaan yang selalu berubah, tidak pasti, dan kompetitif.

Sementara itu Uno (2007:130) mendefinisikan matematika sebbagai aktivitas mental dalam memahami arti dan hubungan-hubungan serta simbol-simbol lalu kemudian diterapkan oleh situasi nyata. Sedangkan menurut Hamzah dan Muhlisrarini (2014:58) berpendapat bahwa matematika merupakan sebuah cabang dari pengetahuan eksak dan terorganisasi, ilmu deduktif tentang keluasan atau pengukuran dan letak tentang bilangan-bilangan dan hubungan-hubungan, ide - ide, struktur dan hubungan yang diatur menurut urutan yang logis tentang struktur logika mengenai bentuk yang terorganisasi atas susunan besaran dan konsep yang mulai dari unsur yang tidak definisikan ke unsur yang didefinisikan, ke aksioma atau postulat 
akhirnya ke dalil atau teorema dan terbagi ke dalam bidang aljabar, analisis dan geometri

Berpijak pada pendapat dari Permendiknas No. 22 Tahun 2006, Uno (2007: 130) dan Hamzah dan Muhlisrarini (2014: 58) dapat ditarik benang merah bahwa matematika merupakan ilmu pengetahuan yang berhubungan memelajari tentang simbol-simbol, bilangan-bilangan dan hubungan-hubungan, ide - ide, konsepkonsep yang di muat ke dalam bidang aljabar, analisis dan geometri yang kemudian digunakan untuk pemecahan masalah yang terjadi ada situasi nyata.

Berdasarkan pada simpulan di atas maka jelaslah bahwa matematika merupakan muatan pembelajaran yang memiliki karakteristik yang berbeda dengan muatan pelajaran lain. Salah satu karakteristik pada muatan pelajaran matematika yaitu ilmu untuk memecahkan masalah.Pemecahan masalah ini berkaitan erat dengan kemampuan siswa untuk dapat berpikir kreatif.

Pehkonen (1999); Krutetskii (1976); Silver (1997) seperti dikutip oleh Sri Hastuti Noer (2011: 106) menyatakan bahwa berpikir kreatif dalam matematika merupakan kombinasi berpikir logis dan berpikir divergen yang didasarkan intuisi tetapi dalam kesadaran yang memperhatikan fleksibilitas, kefasihan dan kebaruan.

Elly's Mersina Mursidik, Nur Samsiyah, dan Hendra Erik Rudyanto (2015) berpendapat bahwa kemampuan berpikir kreatif merupakan kemampuanseseorang dalam mengembangkan ilmu pengetahuan dan teknologi untuk menghasilkan gagasan baru yang dapat digunakan untuk memecahkan masalah yang dihadapinya.

Selanjutnya, Filsaime (2008:56) menyebutkan bahwa kemampuan berpikir kreatif merupakan proses berpikir yang memiliki ciri-ciri kelancaran (fluency), keluwesan (flexibility), keaslian atau originalitas (originality) dan merinci atau elaborasi (elaboration). (1) Kelancaran yaitu kemampuan mengeluarkan ide atau gagasan yang benar sebanyak mungkin secara jelas. (2) keluwesan merupakan kemampuan untuk mengeluarkan banyak ide atau gagasan yang beragam dan tidak monoton dengan melihat dari berbagai sudut pandang. originalitasmerupakan kemampuan untuk mengeluarkan ide atau gagasan yang unik dan tidak biasanya, misalnya yang berbeda dari yang ada di buku atau berbeda dari pendapat orang lain. (4) elaborasi yaitu kemampuan untuk menjelaskan faktor-faktor yang mempenga-ruhi dan menambah detail dari ide atau gagasannya sehingga lebih bernilai

Pada kurikulum 2013, kemampuan pemecahan masalah dalam hal ini kemampuan berpikir kreatif menjadi salah satu kemampuan yang harus dimiliki oleh peserta didik.Dengan demikian sudah seharusnya guru memampu mengembangkan kemampuan tersebut.Salah satu cara yang dapat diterapkan oleh guru dalam proses pembelajaran adalah menggunakan model pembelajaran pemecahan masalah. Miftahul Huda (2013:3) menyebutkan jenis-jenis model pembelajaran pemecahan masalah yaitu Problem Based Learning dan Problem Solving Learning.

Dilihat dari sintaknya, model pembelajaran Problem Based Learning dan Problem Solving Learning memang tidak sama, namun mempunyai satu sisi persamaan, yaitu pembelajaran dititikberatkan pada aktivitas siswa untuk pemecahan masalah. Mencermati berbagai potensi kedua model pembelajaran dan hasil penelitian yang menunjukkan keampuhan kedua model secara empirik, hal ini membingungkan guru dalam memilih model pembelajaran yang akan digunakan dalam pembelajaran karena ke dua model tersebut sama-sama mempunyai potensi dapat diterapkan

dalam membelajarkan konsep-konsep matematika; oleh karena itu perlu dibuktikan model mana yang lebih ampuh untuk diterapkan dalam pembelajaran matematika.

Ngalimun (2013: 89) dan Amir (2009:124) berpendapat bahwa model Problem Based Learning ialah model yang melibatkan siswa dalam memecahkan masalah, dengan awal pembelajaraan menyajikan masalah yang nyata bagi siswa kemudian diselesaikan melalui penyelidikan 
dan diterapkan dengan menggunakan pendekatan pemecahan masalah.

Selanjutnya, Arends (2008:57) menyebutkan sintak dari model Problem Based Learning yaitu: (1) memberikan orientasi permasalahan kepada siswa, (2) mengorganisasikan kepada siswa untuk meneliti, (3) membantu dalam menyelidiki secara mandiri atau berkelompok, (4) mengembangkan dan kemudian mempresentasikan hasil kerja siswa, (5) menganalisis dan mengevaluasi proses dalam mengatasi masalah yang ada.

Model yang sesuai dengan kurikulum 2013 selanjutnya adalah model Problem Solving. Menurut Djamarah (2010) dan Ngalimun (2017), Woolfolk dalam Uno (2008:134) menyatakan bahwa model problem solving merupakan keterampilan siswa dalam menggunakan proses berpikir dalam memecahkan masalah melalui pengumpulan fakta atau mencari data, analisis infromasi, menyusun berbagai altenantif pemecahan atau cara penyelesaian masalah menemukan pola, aturan atau alogoritma) yang efektif. Selanjutnya, Wena (2012:56), menyebutkan sintak Problem
Solving ialah : (a) mengindentifikasi permasalahan, (b) merepresentasi atau menyajikan sebuah masalah, (c) merencanakan untuk pemecahan masalah, (d) menerapkan atau mengimplementasikan perencanaan, (e) enilai dari perencanaan, (f) menilai dari hasil.

\section{METODE PENELITIAN}

\section{Jenis penelitian}

Jenis penelitian ini merupakan penelitian eksperimen semu (quasi eksperimental research).Penelitian ini menggunakan jenis penelitian eksperimen semu atau dikenal dengan eksperimen kuasi.Sugiyono, (2014: 116) berpandangan eksperimen kuasi dapat digunakanapabila mengalami kesulitan dalam mendapatkan kelompok kontrol yang benar-benar dapat mengontrol variabel-variabel luar yang mempengaruhinya.Desain yang digunakan Penelitian ini menggunakan desain Nonequivalent Control Group Design.Adapun gambaran mengenai desain penelitian nonequivalent control group design menurut Johnson \& Christensen (2014).

Gambar 1.Nonequivalent Control Group Design

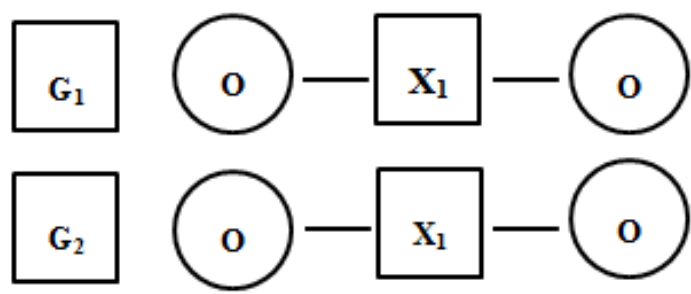

Keterangan :
G1 : Kelompok Eksperimen Pertama
G2 : Kelompok Eksperimen Kedua
O1 : Hasil pretest kelompok eksperimen Pertama
$\mathrm{O}_{2}:$ Hasil posttest kelompok eksperimen Pertama
$\mathrm{X}_{1}:$ Model 1 dengan Problem Based Leaming
$\mathrm{X}_{2}:$ Model 2 dengan Problem Solving
$\mathrm{O}_{3}:$ Hasil pretest kelompok eksperimen kedua
$\mathrm{O}_{4}:$ Hasil posttest kelompok eksperimen kedua

Penelitian eksperimen ini dilakukan di Dabin Putra 3 Serang yang terletak di wilayah Kecamatan Wonosegoro, Kabupaten Boyolali, Jawa Tengah. Materi pembelajaran yang dipilih adalah pengolahan data yang terkait dengan diagram batang, diagram lingkaran dan diagram garis. Langkah-langkah dalam penelitian ini yaitu : memberikan pretest pada kedua kelompok eksperimen. Pemberian pretest digunakan untuk mengetahui kemampuan pada siswa sebelum 
di berikan perlakuan dengan model Problem Based Learning dan kelompok eksperimen II dengan model Problem Solving. Selanjutnya kedua kelas diberikan posttest setelah mendapatkan perlakuan. Soal posttest digunakan untuk mengetahui ada tidaknya pengaruh dari perlakuan antara model Problem Based Learning dan Problem Solving.

\section{Teknik Pengumpulan Data}

Data penelitian dikumpulkan melalui tes dan nontes untuk kedua kelompok eksperimen. Tes yang digunakan dalam penelitian ini yaitu tes kemampuan berpikir kreatif berupa tes awal (pretest) dan tes akhir (posstest) yang berbentuk dalam tes uraian. Sedangkan nontes terdiri atas lembar observasi guru dan siswa, yang digunakan untuk mengukur atau menilai hasil serta proses belajar seperti tingkah laku guru, kegiatan diskusi siswa serta digunakan untuk melihat kesesuaian penerapan pada langkahlangkah pembelajaran.

Adapun langkah yang diggunakan untuk mengumpulkan data sebagai berikut; menyusun kisi-kisi, menyusun instrument penelitian, melakukan uji validitas dan reliabilitas menggunakan SPSS 20.0 for windows, memberikan pretest, melakukan tindakan penelitian, memberikan tindakan penelitian, memberikan posttest, dan menganalisis data.

\section{Teknik analisis data}

Analisis data dilakukan dengan menggunakan analisis deskriptif dan uji normalitas, dan uji homogenititas, sebagai uji prasyarat sebelum dilakukan uji beda rata-rata dan uji hipotesis. Analisis deskriptif dilakukan untuk mendeskripsikan keadaan sebelum dan sesudah diberikan perlakuan pada kedua kelompok eksperimen terhadap kemampuan berpikir kreatif dengan materi pengolahan data.Selanjutnta uji normalitas digunakan untuk melihat penyebaran data pada kelompok eksperimen I dan kelompok eksperimen II berdistribusi normal atau tidak.Uji normalitas pada penelitian ini menggunakan teknik uji KolmogorovSmirnov Zdengan SPSS 20.0 for windows.Sedangkan dengan uji homogenitas digunakan untuk mengetahui apakah sampel pada kelas ekperimen I dan kelas eksperimen II sebelum memiliki variasi yang sama.Setelah melakukan uji prasyarat dengan uji normalitas dan homogenitas, selanjuta dilakukan dengan uji $\mathrm{T}$ dengan Independent Sample T-Test untuk menganalisis keefektifan model Problem Based Learning dan Problem Solving terhadap kemampuan berpikir kreatif matematika. Data yang dianalisis merupakan data posttest. Selanjutnya dilakukan dengan uji hipotesis, kriteria keputusannya yaitu $\mathrm{H}_{0}$ ditolak jika $t_{\text {hitung }}>t_{\text {tabel }}$, serta dengan nilai signifikansi diatas $(>0,05)$. Setelah diketahui keefektifan model terhadap kemampuan berpikir kreatif, selanjutnya dilakukan dengan analisis data untul mengetahui yang lebih efektif. Untuk memperkuat keefektifan dilakukan pada kelompok eksperimen I dan kelompok eksperimen II dilakukan dengan uji normalitas gain.

\section{HASIL PENELITIAN DAN PEMBAHASAN \\ 1. Hasil penelitian \\ Data yang diperoleh dalam penelitian ini yaitu data posttest dan pretest kemampuan berpikir kreatif matematika.Adapun komparasi hasil pengukuran kemampuan berpikir kreatif tersaji didalam tabel 1 .}

Tabel 1.Komparasi Tingkat kemampuan Berpikir Kreatif

\begin{tabular}{llll} 
Tahap & \multicolumn{2}{l}{ Rara-rata Skor (Mean) } & Selisih \\
Pengukuran & Eksperimen I & Eksperimen II & \\
Pretest & 9,28 & 7,55 & 1,73 \\
Postest & 17,44 & 10,70 & 6,74
\end{tabular}

Berdasarkan hasil dari komparasi rata-rata pada tabel 1, rata-rata skor pretest antara kelompok ekperimen I yang mendapatkan perlakuan model Problem Based 
Learningdan kelompok ekperimen yang mendapat perlakuan Problem Solving terdapat perbedaan sebesar 1,73. Sedangkan untuk rata-rata skor pada posttest antara kelompok eksperimen I dan kelompok eksperimen II terdapat perbedaan sebesar
6,74. Adapun data dari diagram komparasi data pada kelompok eksperimen I dan kelompok eksperimen II tersaji dalam gambar 1

\section{Gambar 2. Komparasi Hasil Pengukuran Kemampuan Berpikir Kreatif}

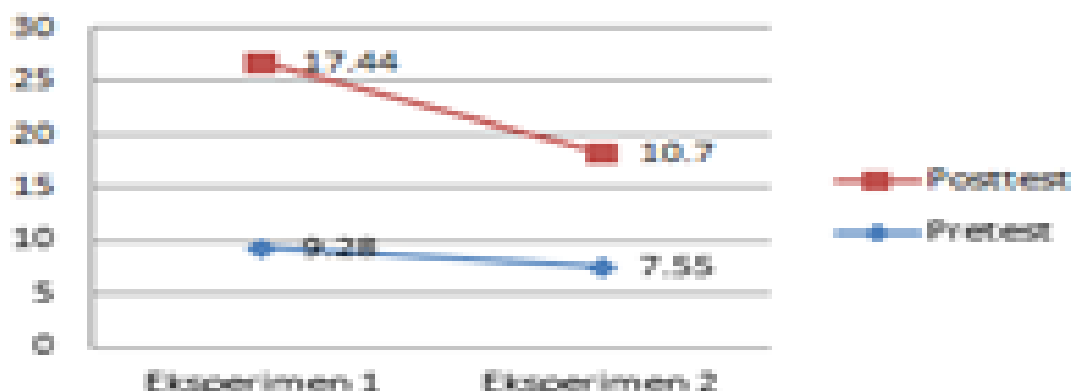

Berdasarkan gambar 1 diketahui adanya peningkatan data pada kelompok eksperimen I yang mendapat perlakuan dengan model
Problem Based Learning maupun kelompok eksperimen II yang mendapat perlakuan dengan model Problem Solving.

Tabel 3. Hasil Normalitas Data Keterampilan Berpikir Kritis Pretest-Postest

\begin{tabular}{|c|c|c|c|c|c|}
\hline \multicolumn{6}{|c|}{ One-Sample Kolmogorov-Smirnov Test } \\
\hline & & $\begin{array}{c}\text { pretes_ekspe } \\
\text { rimen1 }\end{array}$ & $\begin{array}{c}\text { postes_eksp } \\
\text { erimen1 }\end{array}$ & $\begin{array}{c}\text { pretes_ekspe } \\
\text { riman2 }\end{array}$ & $\begin{array}{c}\text { postes_eksp } \\
\text { erimen2 }\end{array}$ \\
\hline 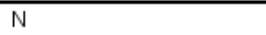 & & 18 & 18 & 20 & 20 \\
\hline \multirow{2}{*}{ Normal Parameters ${ }^{a, b}$} & Mean & 9.28 & 17.44 & 7.55 & 10.70 \\
\hline & Std. Deviation & 1.934 & 1.149 & 1.877 & 2.598 \\
\hline \multirow[t]{3}{*}{ Most Extreme Differences } & Absolute & .188 & .186 & .146 & .194 \\
\hline & Positive & .188 & .173 & .146 & .194 \\
\hline & Negative & -.143 & -.186 & -.145 & -.148 \\
\hline Kolmogorov-Smirnov Z & & .797 & .788 & .651 & .866 \\
\hline Asymp. Sig. (2-tailed) & & .550 & .565 & .791 & .442 \\
\hline
\end{tabular}

Berdasarkan tabel 3 dapat diketahui hasil uji normalitas hasil berpikir kreatif pretest dan posttest pada kelas eksperimen 1 dan 2 . Uji normalitas menggunakan teknik Kolmogorov-Smirnov Z dengan SPSS 20.0 for windows, jika nilai signifikansi $<0,05$ maka dapat dikatakan berdistribusi tidak normal. Apabila nilai signifikansi >0,05 maka data berdistribusi normal. Berdasarkan data di atas artinya data berdistribusi normal.

\section{Uji Beda Rerata}

Berdasarkan uji prasyarat yang telah dilakukan, diketahui bahwa data berdistribusi normal dan homogeny.Selanjutnta dilakukan dengan analisis uji $\mathrm{T}$ menggunakan Independent Sample Test dengan bantuan SPSS 20.0 for windows untuk mengetahui ada tidaknya perbedaan efektifitas antara kedua kelompok eksperimen terhadap kemampuan berpikir kreatif matematika.Hasil dari analis menggunakan uji T disajikan pada tabel 4 .

Tabel 4 Uji T Independent Sample Test

\begin{tabular}{|c|c|c|c|c|c|c|c|c|c|c|}
\hline \multicolumn{11}{|c|}{ Independent Samples Test } \\
\hline & & \multicolumn{2}{|c|}{$\begin{array}{l}\text { Levene's Test for Equality of } \\
\text { Variances }\end{array}$} & \multicolumn{7}{|c|}{ t-test for Equality of Means } \\
\hline & & \multirow[b]{2}{*}{$\mathrm{F}$} & \multirow[b]{2}{*}{ Sig. } & \multirow[b]{2}{*}{$t$} & \multirow[b]{2}{*}{ df } & \multirow[b]{2}{*}{ Sig. (2-tailed) } & \multirow{2}{*}{$\begin{array}{c}\text { Mean } \\
\text { Difference }\end{array}$} & \multirow{2}{*}{$\begin{array}{l}\text { Std. Error } \\
\text { Difference }\end{array}$} & \multicolumn{2}{|c|}{$\begin{array}{l}95 \% \text { Confidence Interval of the } \\
\text { Difference }\end{array}$} \\
\hline & & & & & & & & & Lower & Upper \\
\hline postest & $\begin{array}{l}\text { Equal variances } \\
\text { assumed }\end{array}$ & 13.701 & .001 & 10.148 & 36 & .000 & 6.744 & .665 & 5.397 & 8.092 \\
\hline & $\begin{array}{l}\text { Equal variances not } \\
\text { assumed }\end{array}$ & & & 10.524 & 26.747 & .000 & 6.744 & .641 & 5.429 & 8.060 \\
\hline
\end{tabular}


Hasil dari uji $\mathrm{T}$ pada tabel 4 menunjukkan $t_{\text {hitung }}$ sebesar 10,148 dengan signifikansi pada kolom Sig,(2-tailed) sebesar 0,00. Berdasarkan data analisis data diketahui $t_{\text {tabel }}$ diperoleh sebesar 2.0281 ,sedangkan untuk mengetahui $\mathrm{t}_{\text {tabel }}$ dengan bantuan bantuan MS. Excel yaitu dengan menuliskan

$\{=\mathrm{TINV}$ (probability:deg_freedom)\}

probability merupakan tingkatan signifikan yang dipakai yaitu sebesar $5 \%(0,05)$, sedangkan deg_freedom merupakan $\mathrm{df}$ berdasarkan hasil uji t yaitu sebesar 36 .

\section{Uji Hipotesis}

Berdasarkan tabel 4 hasil analisis Independent Sample T-Test. Kemudian dilakukan uji hipotesis penelitian.Pengujian hipotesis merupakan langkah untuk menentukan apakah hipotesis diterima atau ditolak.Hipotesis yang diajukan dalam penelitian ini yaitu.

$\mathrm{H}_{0}$ : Tidak terdapat efektifitasyang signifikan dalam penerapan model pembelajaran Problem Based Learning $(P B L)$ dan Problem Solving pada siswa kelas 4 SD

$\mathrm{H}_{\mathrm{a}} \quad$ Terdapat perbedaan efektifitas yang signifikan dalam penerapan model pembelajaran Problem Based Learning $(P B L)$ dan Problem Solving pada siswa kelas 4 SD

Untuk menguji hipotesis maka digunakan hasil outpit olahan SPSS 20.0 for windows.

Kriteria pengujian:

a. Menggunakan koeisien Sig. dengan ketentuan

1. Jika nilai sig $<0,05$ maka tolak $\mathrm{H}_{0}$

2. Jika nilai sig $>0,05$ maka diterima $\mathrm{H}_{0}$

b. Menggunakan koefisien t hitung dengan ketentuan

1. Jika koefisien $t$ hitung $>t$ tabel maka tolak $\mathrm{H}_{0}$

Tabel 5. Ketegori perolehan Skor N-gain
2. Jika koefisien $\mathrm{t}_{\text {hitung }}<\mathrm{t}$ tabel maka terima $\mathrm{H}_{0}$

Hasil perhitungan uji hipotesis menggunakan uji $t$ Independent Sample Test. Berdasarkan tabel menunjukkan skor koefisien $\mathrm{t}$ sebesar 1,688 dengan nilai signifikan sebesar 0,000 yang berarti lebih kecil dari $0,05 \quad(0,00<0,05)$. Dari uji $t$ menunjukkan $\mathrm{t}$ hitung $>\mathrm{t}$ tabel 10,148 $>2.0281$ dan signigikan $0,000<0,05$ yang menunjukkan bahwa $\mathrm{H}_{0}$ ditolak $\mathrm{H}_{\mathrm{a}}$ diterima. Hal ini menunjukkan bahwa ada perbedaan pengaruh yang signifikan dalam penerapan model pembelajaran Problem Based Learning dan Problem Solving terhadap kemampuan berpikir kreatif pada siswa kelas 4SD

Selanjutnya berdasarkan hasil uji beda ratarata posttest terlihat bahwa nilai dari kemampuan berpikir kreati pada kelompok ekperimen I lebih tinggi dibandingkan kelompok eksperimen II. Hal ini menunjukan bahwa perlakuan yang diberikan kepada kelompok eksperimen I lebih efektif dibandingkan dari perlakuan kepada kelompok eksperimen II. Untuk memperkuat keefektifan pada kelompok eksperimen, maka dapat dianalisis dengan menggunakan uji normalitas gain. Untuk menghitung $\mathrm{N}$-gain antara posttest dan pretest dapat menggunakan rumus Hake (Meltzer,2002). Sedangkan kategori perolehan skor $\mathrm{N}$-gain dapat dilihat pada tabel 6 .

Keterangan :

$$
N-\text { gain }=\frac{S \text { posttest }-S \text { pretest }}{S \text { max }-S \text { pretest }}
$$

$\begin{array}{ll}\text { S postest } & \text { : skor postest } \\ \text { S pretest } & \text { : skor postest } \\ \text { S max } & : \text { skor maksimum } \\ \text { ideal } & \end{array}$

Sedangkan kriteria perolehan skor N-gain dapat diliihat dalam tabel berikut.

\begin{tabular}{|c|c|}
\hline Fiatasam & Fategori \\
\hline$\equiv=0.07$ & 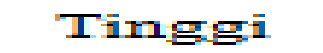 \\
\hline 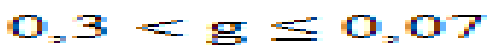 & Sedamp \\
\hline$\equiv=0.3$ & Fremclaln \\
\hline
\end{tabular}


Hasil uji normalitas gain pada kelas eksperimen I menunjukkan bahwa rata-rata kelas eksperimen I mengalami peningkatan sebesar 0,54 yang berarti $\mathrm{N}$-gain rata-rata kelas eksperimen I termasuk peningkatan kategori sedang. Sedangkan peningkatan di dalam kelas eksperimen II sebesar 0,28 termasuk peningkatan kategori rendah.

Pada kelas eksperimen I secara keseluruhan siswa memiliki peningkatan nilai kemampuan berpikir kreatif dalam kategori sedang dan hanya 2 orang yang memiliki peningkatan dalam kategori rendah, sedangkan pada kelas eksperimen II secara keseluruhan siswa memiliki peningkatan nilai kemampuan berpikir kreatif dalam kategori sedang dan 12 orang yang memiliki peningkatan dalam kategori rendah. Sehingga secara keseluruhan dapat disimpulkan bahwa model Problem Based Learning lebih efektif terhadap kemampuan berpikir kreatif matematika pada siswa kelas 4 SD.Sehingga secara keseluruhan dapat disimpulkan bahwa model CIRC lebih efektif terhadap kemampuan pemecahan masalah matematika pada siswa kelas IV SD.

\section{SIMPULAN DAN SARAN}

Dalam penelitian ini dapat disimpulkan terdapat perbedaan efektifitas yang signifikan dalam penerapan model pembelajaran Problem Based Learning dan Problem Solving terhadap kemampuan berpikir kreati matematika siswa kelas 4 SD. hal ini dengan bersarkan dengan hasil uji prasyarat yang telah dilakukan yaitu uji normalitas dan homogenitas menunjukan signidikansi atau probabilitas normal dan homogeny. Selanjutnya dilakukan dengan uji t Independent Sample Test. Diketahui dengan nilai koefisien $\mathrm{t}$ sebesar 1,688 dengan nilai signifikan sebesar 0,000 yang berarti lebih kecil dari $0,05 \quad(0,00<0,05)$. Dari uji $\mathrm{t}$ menunjukkan $\mathrm{t}$ hitung $>\mathrm{t}$ tabel $10,148>2.0281$ dan signifikan $0,000<0,05$ yang menunjukkan bahwa $\mathrm{H}_{0}$ ditolak $\mathrm{H}_{\mathrm{a}}$ diterima. Hal ini menunjukan adanya perbedaan pengaruh yang signifikan dalam penerapan model Problem Based Learning dan Problem Solving terhadap kemampuan berpikir kreatif kelas 4 SD. selanjutnya dilakukan dengan uji normalitas untuk melihat peningkatan pada kelas eksperimen I sebesar dan kelas eksperimen II sebesar. Sehingga dapat disimpulkan bahwa perlakuan di kelas eksperimen I dengan menggunakan model Problem Based Learning lebih efekti terhadap kemampuan berpikir kreatif matematika pada siswa kelas 4 SD.Saran yang dapat diajukan untuk keterlaksanaan proses pembelajaran dalam kelas sesuai dengan kurikulum 2013 dengan menerapkan model Problem Based Learning dan Problem Solving sebagai alternatif dalam meningkatkan kemampuan berpikir kreatif matematika siswa SD. Namun dalam penerapan perlu diperhatikan dalam karakteristik dan kondisi siswa dan sekolah.

\section{DAFTAR RUJUKAN}

Amir, T. 2009.Inovasi Pendidikan Melalui Problem Based Learning. Jakarta: Kencana Prenada Media Group.

Amir, Taufiq. 2009. Inovasi PendidIkan Melalui Problem Based Learning. Jakarta: Kencana Prenada Media Group.

Arends, L. Richard. 2008. Learning To Teach. Yogyakarta: Pustaka Pelajar

B. Uno, Hamzah. 2008. Teori Motivasi Dan Pengukurannya, Jakarta : Bumi Aksara

Budiyono. 2009. Statistika Untuk Penelitian Edisi Ke-2. Surakarta: Sebelas Maret University Press.

Depdiknas. 2006. Lampiran Permendiknas No. 22 Tahun 20016 Tentang Standar Proses SD/MI Tahun 2016. Jakarta: Depdiknas.

Djamarah, Syaiful Bahri Dan Aswan Zain. 2010. Strategi Belajar Mengajar.Jakarta: Rineka Cipta

Filsaime,D.K. 2008. Menguak Rahasia Berpikir Kritis Dan Kreatif.Jakarta : Prestasi Pustaka

Gay, 1987, L.R. 1987. Educational Research. New York: Merrill And Macmillan Pub. And Co.

Hamzah, Ali Dan Muhlisrarini. 2014. Perencanaan dan Strategi Pembelajaran Matematika. Jakarta: Raja Grafindo Persada 
Huda, Miftahul. 2013. Model-Model Pengajaran Dan Pembelajaran.Yogyakarta: Pustaka Pelajar

Ibrahim, M., \& Prajono, R. (2017).Efektivitas Model Pembelajaran Problem Based Learning Dalam Peningkatan Kemampuan Berpikir Kreatif Matematika Siswa Kelas Viii Smp Negeri 1 Siompu Barat. Jurnal Penelitian Pendidikan Matematika, 3(2), 91-103.

Meltzer, (2002), The relationship Between Mathematics Preparation and Conceptual Learning Gain in Physics : A Posible "Hidden Variable in Diagnostic Pretest Score", American Journal Physics

MULYANINGSIH, R. R. S. S., Lasmawan, I. W., \& Sutama, I. M. (2013).Pengaruh Model Problem Solving Berbasis Budaya Lokal Terhadap Motivasi Berprestasi dan Prestasi Belajar IPS. PENDASI: Jurnal Pendidikan Dasar Indonesia, 3(1).

Ngalimun.2013. Strategi Dan Model Pembelajaran.Yogyakarta : Aswaja Pressindo

Ngalimun.2013. Strategi Dan Model Pembelaran. Aswaja Pressindo. Yogyakarta

Ngalimun.Strategi Pembelajaran. 2017.Yogyakarta: Dua Satria Offet

Noer, S. H. (2011).Kemampuan berpikir kreatif matematis dan pembelajaran matematika berbasis masalah Open-Ended.Jurnal Pendidikan Matematika, 5(1).

Nurlaila, N., Suparmi, S., \& Sunarno, W. 2013.Pembelajaran Fisika Dengan PBL Menggunakan Problem Solving Dan Problem Posing Ditinjau Dari Kreativitas Dan Keterampilan Berpikir Kritis Siswa. INKUIRI: Jurnal Pendidikan IPA, 2 (02)

Rahmawati, E. 2010. Efektivitas Model Pembelajaran Problem Solving Dalam Materi Sistem Persamaan Linier Dua Variabel Di Kelas VIII
Mtsn Tanjung Tani Prambon Nganjuk Tahun Pelajaran 2009/2010 (Doctoral Dissertation, IAIN Walisongo).

Samsiyah, N., \& Rudyanto, H. E. (2015).Kemampuan Berpikir Kreatif Dalam Memecahkan Masalah Matetatika Open-Ended Ditinjau Dari Tingkat Kemampuan Matematika Siswa Sekolah Dasar. PEDAGOGIA: Jurnal Pendidikan, 4(1), 23-33.

Sugiyono. 2014. Metode Penelitian Pendidikan Pendekatan Kuantitatif, Kualitatif Dan R\&D. Bandung: Alfabeta.

Udin, T., \& Hikmah, N. 2014). Pengaruh Penerapan Metode Problem Solving Terhadap Hasil Belajar Siswa Mata Pelajaran Matematika Pokok Bahasan Pecahan Pada Siswa Kelas IV SD Negeri Legok 1 Kabupaten Indramayu. Al Ibtida: Jurnal Pendidikan Guru MI, 1(1).

Uno, Hamzah B. 2007. Model Pembelajaran Menciptakan Proses Belajar Mengajar Yang Kreatif dan Efektif. Jakarta: Bumi Aksara.

Wena, Made. 2012. Strategi Pembelajaran Inovatif Kontemporer. Jakarta: Bumi Aksara 